\title{
THE RELATIONSHIP BETWEEN PSYCHOLOGICAL WELLBEING AND WORK MOTIVATION AMONG STAFF NURSES IN GOVERNMENTAL HOSPITALS IN PORT SAID
}

\author{
Amal Sobhy Mahmoud ${ }^{1}$, WafaaAbd-Elazeem Elhosany ${ }^{2}$, Ola Mahmoud Helal ${ }^{3}$ \\ Professor of Psychiatric Nursing and Mental health, Faculty of Nursing, Port Said \\ University $^{l}$; Assistant Professor of Nursing Administration, Faculty of Nursing, Suez \\ Canal University ${ }^{2}$; M.Sc, Faculty of Nursing, Port Said University ${ }^{3}$
}

\begin{abstract}
Background: Nurses are a main group of health service providers, but they have to face physical and psychological problems such as permanent confrontation with the patient, being exposed to health hazards. Nurses need to be motivated to accomplish their tasks, provide quality care. Motivation at work was found to be closely linked with job satisfaction and psychological well-being. Aim: the aim of the study was to investigate the relationship between psychological wellbeing and work motivation among staff nurses in Governmental Hospitals in Port Said. Subject and Methods: The current study utilized a descriptive correlational design. The study population included all staff nurses with total number 274 at inpatient units working in four hospitals namely (Port Said general hospital, Elnasr hospital, Elzohor Central hospital and Port Fouad general hospital), used two tools: Ryff Psychological Wellbeing Scale (Ryff Scale), Work Preference Inventory scale, a personal and job characteristics questionnaire sheet was added. Results: The high percentage of nurses participate in this study were females $94.2 \%$, less than three quarter of studied staff nurses had high level of the total psychological well-being (71.5\%), the majority of the studied staff nurses had highly total scores of work motivation (77.4\%).Conclusions: there is a significant correlation between psychological wellbeing and work motivation among staff nurses in governmental hospitals at Port Said. Recommendations: Nurses should improve their psychological wellbeing state. In addition, nurses' managers should motivate nurses through increase incentives, appreciate and acknowledge all nurses working in hospitals.
\end{abstract}

Keywords: Hospital nurses, Psychological wellbeing and Work motivation. 


\section{INTRODUCTION}

Nurses are a main group of health service providers, but they have to face physical and psychological problems such as being exposed to health hazards, dealing with critically ill patients, the lack of adequate equipment (Huppert, 2009).Nurses who work in such environment must be encouraged to provide patients with excellent nursing care (Disch, 2002; Aiken, Sermeus, Van den Heede, Sloane, Busse, et al., 2012).

Maintaining a highest possible level of well-being for all healthcare providers is one of the primary goals of the World Health Organization (World Health Organization, 2012). While nurses are the cornerstone in providing a high level of quality of patient care; they require attaining a high level of physical and psychological wellbeing for themselves in the first place and for the patients (Nemcek \& James, 2007).

Psychological wellbeing focuses on the positive and negative emotions. Psychological wellbeing consists of six dimensions, including autonomy (independence and selfdetermination) environmental mastery (the ability to manage one's life), personal growth (being open to new experiences), purpose in life (believing that one's life is meaningful), self-acceptance (a positive attitude towards oneself and one's past life) and positive relations with others (high quality relationships) (Bhardwaj \& Srivavastava, 2008).

Psychological wellbeing, is affected when negative emotions are extreme or extensive and when they interfere with the employees' ability to do their daily work activities effectively (Huppert, 2009). According to Keyes (2000), employees' psychological wellbeing refers to their perception of how the quality of their work life could affect their physical, emotional and social functioning (Registered Nurses Association of Ontario, 2008).

Three main domains that describe the psychological well-being: social-role functioning (SRF), interpersonal relationships (IR), and symptom distress (SD). Social role functioning measures the employees' work relations. Interpersonal relationship assesses the employees' satisfaction with their relationships and the Symptom distress entails the general emotional, lifestyle stressors (Northern Ireland Civil Service, 2009).

Nurses'motivation is the key factor for organizational success (Ostraker, 2008). Motivation is an effective instrument in the hand of management in inspiring the work force; motivation increases the willingness of the worker to work thus increasing efficiency and effectiveness of the organization (Samith, 2009). 
Nurses 'professional performance can be defined as a product of motivation and abilities of the nurse (Trossman, 2006). Motivated nurses have reported stronger behavioral, verbal outcome and empowerment than un motivated nurses who has low work motivation (Suominen, Leino-Kilpih, Merj, Doran \&Puukka, 2008).

Motivation at work was found to be closely linked with job satisfaction and psychological well-being, nurses need to be motivated to accomplish their tasks and provide quality care (Engin \& Com, 2006).

Significance of the study:

Most staff nurses have to do shift work or attend emergencies at night; this may be a source of depression, low motivation and the pressures of working long hours at the expense of their health (Srinivasn \&Samuel, 2014).

Hence, the assessment of psychological wellbeing of staff nurses is essential. Also, nurses need to be encouraged to provide patients with excellent nursing care. Therefore, this study investigates the relationship between psychological wellbeing and work motivation among staff nurses in governmental hospitals in Port Said.

\section{AIM OF THE STUDY:}

This study aims to investigate the relationship between psychological wellbeing and work motivation among staff nurses in Port Said Governmental Hospitals through:

\section{Objectives:}

1. Assessing six dimensions of psychological wellbeing among staff nurses.

2. Determine the level of work motivation among staff nurses.

3. Finding out the relationship between psychological wellbeing and work motivation among staff nurses.

\section{Research Questions:}

1. What are the levels of psychological wellbeing among staff nurses in governmental hospitals at Port Said?

2. What are the levels of work motivation among staff nurses in governmental hospitals at Port Said?

3. Is there a relationship between psychological wellbeing and work motivation among staff nurses in governmental hospitals at Port Said? 


\section{SUBJECTS AND METHODS:}

\section{Research Design:}

A descriptive correlational research design was used in this study.

\section{Study Setting:}

This study was conducted at inpatient units of four governmental hospitals in Port Said Governorate namely: Port-Said General hospital, El-Nasr General hospital, El-Zohour Central hospital and Port-Fouad General hospital.

\section{Study Subjects:}

The study subject will include staff nurses in morning, afternoon and night shift at inpatient units of governmental hospitals at Port Said Governorate. Staff nurses at inpatient units are 274 staff nurse. They are distributed as following:

\begin{tabular}{|l|l|}
\hline Hospital Name & Sample Size \\
\hline Port-Said General Hospital & 110 \\
\hline El-Nasr General Hospital & 63 \\
\hline El-Zohour Central Hospital & 50 \\
\hline Port- Fouad General Hospital & 51 \\
\hline
\end{tabular}

\section{*Inclusion criteria:}

Nurses hold a secondary nursing diploma.

\section{Tool for Data Collection:}

Data of this study collected using two tools these included

\section{Tool I: Ryff Psychological Wellbeing Scale (Ryff Scale):}

It developed by Ryff (1989), modified by Ryff\& Singer (1996) and translated into Arabic language by the researcher. The tool used to assess psychological wellbeing among staff nurses. It consists of 42 questions divided into 6 dimensions of psychological wellbeing: autonomy, environmental mastery, personal growth, purpose in life, selfacceptance and positive relations with others. Each dimension contains seven questions. Autonomy sentences are 1, 7, 13R, 19R, 25, 31R and 37. Environmental mastery 
sentences are 2, 8, 14R, 20,26R, 32R, and 38. Personal growth sentences are 3R, 9, 15R, 21, 27R, 33, and 39R. Self-acceptance sentences are 6, 12, 18 R, 24, 30R, 36R, and 42. Positive relations with others sentences are $(4,10 \mathrm{R}, 16 \mathrm{R}, 22,28,34 \mathrm{R}$ and 40. Purpose in life sentences are 5R, 11, 17R, 23R, 29, 35 and 41R. " $R$ " denotes reversed scored items Participants' answers using a six-point Likert scale where 1 indicating strongly agree to 6 indicating strongly disagree.

\section{Scoring System:}

For each domain, the scores of the items were summed-up and the total was divided by the number of the items, giving a mean score for the part. These scores were converted into a percentage score. The total possible score for Psychological Well-being range from 42 to 252 . Psychological wellbeing was considered high if the percent score was $\geq 60 \%$, and low if the percent score was $<60 \%$ (NIOSH, 2002).

\section{Tool II: Work Preference Inventory:}

Amabile (1987) developed work preference inventory and translated into Arabic language by the researcher. It was designed to assess individual differences in intrinsic and extrinsic motivational orientations. It consists of 30 items in two domains: intrinsic and extrinsic motivations. Each domain represents two sub factors: intrinsic motivation is composed of challenge (5 items) and Enjoyment (10 items), but extrinsic motivation is composed of two sub-factors compensation (5 items) and outward orientation (10items). The scoring system is that responses were on a 4-degree likert scale from (never or almost never true) to (always or almost true).

\section{Scoring System:}

Motivation items were scored 1, 2, 3 and 4 for the responses (always or almost always true of you, often true of you, sometimes true of you, never or almost never true of you) respectively. For each domain, the scores of the items were summed-up and the total divided by the number of the items, giving a mean score for the part. These scores were converted into a percentage score. The total possible score for Motivation can range from 30 to 120 . Motivation was considered high if the percent score was $\geq 60 \%$, and low if the percent score was $<60 \%$ (NIOSH, 2002).

In addition, personal and job characteristics questionnaire was added, personal and job characteristics questionnaire which was developed by the researcher after review of 
literature. It includes questions related to personal characteristics of staff nurses (name, age, sex, qualification, years of experience, hospital, unit,....etc).

\section{Content Validity:}

It was ascertained by a Jury consisting of nine experts in different fields of nursing. They were requested to express their opinions and comments on the translated tools (Tool I, II). The process of translation- re-translation was used to ensure the validity of the translated tools. This phase was carried out in a period of two months.

\section{Reliability of the Tools:}

Cronbach's Alpha co-efficient was calculated to assess the reliability of the translated tools (Tool I, II) through their internal consistency. This phase was conducted within one month.

\section{Reliability of the translated tools (Tool I, II)}

\begin{tabular}{|l|l|l||}
\hline Scale & Items & Cronbach's Alpha \\
\hline Ryff Psychological Wellbeing Scale & 7 & 0.71 \\
\hline Autonomy & 7 & 0.79 \\
\hline Self-acceptance & 7 & 0.78 \\
\hline Positive relations with others & 7 & 0.68 \\
\hline Environmental mastery & 7 & 0.82 \\
\hline Purpose in life & 7 & 0.71 \\
\hline Personal growth & & \\
\hline Work Preference Inventory & 15 & 0.75 \\
\hline Intrinsic motivation & 15 & 0.70 \\
\hline Extrinsic motivation & & \\
\hline
\end{tabular}

\section{Pilot Study:}

The pilot study was carried out on $10 \%$ of the study subjects, which represented 28 nurses selected randomly from one of the randomly selected hospital to test the tools before starting the data collection phase, and they were excluded from the entire sample of the research work. Purposes of the pilot study were to test the applicability of the study tools, and it served to estimate the time needed to complete the tools. Based on the findings of the pilot study, no modifications carried out on the tools, it was simple and 
clears for the nurses. Nurses completed the study tools within a period of one and half hour. It was conducted on 1 May 2016.

\section{Field Work:}

- Before starting any steps in the study, an official letter was addressed from the dean of the faculty of nursing to the directors of the identified study settings requesting their cooperation and permission to conduct the study.

- Also, an official permission from the directors of the studied hospitals was obtained.

- Before distributing the questionnaires, the researcher met the subjects and explained the purpose of the study, the components of the tools, the information obtained would be confidential as well as the method of filling them every nurse took 30-45 minutes for both tools.

- The data were collected from all staff nurses in the study from the previous setting according to the previous criteria using self-instructions questionnaires.

- Data were collected by the researcher from staff nurses at three days per week in afternoon and evening shifts after explaining the objectives of the study and how to complete the tool.

- A number of 4-6 nurses were interviewed in morning shift but 3-5 nurses in afternoon shift, 1-3 nurses in night shift. The researcher appointee the missed nurse in the next visit

- Data were then categorized by the researcher, checked, and revised.

- This process of data collection was carried out in the period started since June 2015 to the end of May 2016.

\section{Ethical Considerations:}

- An official permission through formal agreement were taken from hospital medical and nursing directors to carry out the study.

- The aim of the study was explained to each staff nurses who included in the study to be familiar with the importance of their participations and obtain their permission to participate was taken.

- Staff nurses included in the study were assured about confidentiality of the information gathered and it was used only for the purpose of the study.

- The studied staff nurses were informed that they have right to withdraw from study at any time 


\section{Statistical Design:}

Data entry and statistical analysis were done using SPSS Version 16.0 statistical software package. Data were presented using descriptive statistics in the form of frequencies and percentages for qualitative variables, and means and standard deviations for quantitative variables. Qualitative categorical variables were compared using chisquare test. In addition, correlation coefficient test was used was used for assessment of the inter-relationships among quantitative variables and ranked ones. Statistical significance was considered at $\mathrm{p}$-value $<0.05$.

\section{RESULTS:}

The present study was included 274 nurses, their age ranges between 20 to 57 years old with mean ages $32.3 \pm 7.9$ years, less than one half of staff nurses were in age group $20-<30$ years old $(44.5 \%), 94.2 \%$ of them were females, more than two third of staff nurses were married or divorced(77.4\%).

Regarding the job characteristics of the studied staff nurses; a study result indicates that the highest percentages of participants are nurses (98.9\%). The results revealed that most of studied staff nurses are worked in Port-said general hospital (40.1\%) compared to 23.1\% are worked in El-Nasr hospital, 18.6\% worked in Port Fouad hospital, while, $18.2 \%$ of them worked in El-Zohour hospital.

The study result indicates that the majority of the studied staff nurses working in ICU and CCU units $(38.7 \%)$ followed by about one quarter of them working in internal medical surgical ward $(25.2 \%)$. While the minority of the studied staff nurses working in laparoscope and catheter units respectively (1.5\%). Also, this table show concerning years of experience, the majority of staff nurses had period of experience in nursing more than ten years $(43.1 \%)$.

Table (1): reflects psychological wellbeing domains scores among studied staff nurses, less than three quarter of studied staff nurses had high level of the total psychological wellbeing $(71.5 \%)$ with a mean scores \pm SD $(64.0 \pm 7.1)$. The table also illustrates that most of the studied staff nurses had highly scores in personal growth $(69.0 \%)$ with mean score \pm SD $(66.7 \pm 10.9)$ followed by about two third of them had highly scores in environmental mastery $(66.4 \%)$ with mean score \pm SD $(64.9 \pm 10.1)$. On the other hand, less than half of the studied staff nurses had low scores of autonomy and purpose in life $(44.1 \%, 43.1 \%$ respectively). 
Table (2):describes that the majority of the studied staff nurses had highly total scores of work motivation with the mean score $\pm \mathrm{SD}(67.8 \pm 10.6)$ and more than three quarter of them reported highly scores for extrinsic motivation (79.6\%) with mean score $\pm \mathrm{SD}$ $(69.1 \pm 12.9)$.

Table (3): there is a statistically positive significant correlation between total score of psychological well-being in relation to the total score of work motivation $(r=0.314)$. Also, there was a statistically positive significant correlation was found between all psychological well-being domains in relation total score of work motivation except in personal growth domain.

Table (4): revealed that there is a statistically positive significant correlation between total score of psychological well-being in relation to the total score of intrinsic work motivation ( $\mathrm{r}=0.239)$. Also, there was a statistically positive significant correlation was found between most psychological well-being domains in relation total score of intrinsic work motivation. While, there is no statistically significant correlation between autonomy, personal growth in relation to intrinsic work motivation ( $\mathrm{r}=0.134$ and 0.09 respectively).

Table (5): presents that there is a statistically positive significant correlation between total score of psychological well-being in relation to the total score of extrinsic work motivation $(\mathrm{r}=0.319)$. Also, there was a statistically positive significant correlation was found between all psychological well-being domains in relation to the total score of extrinsic work motivation except in personal growth domain. 
Table (1): Psychological well-being domains scores among studied staff nurses ( $n=274)$.

\begin{tabular}{|l|c|c|c|c|c|c|}
\hline \multirow{2}{*}{$\begin{array}{l}\text { Psychological wellbeing } \\
\text { Domains }\end{array}$} & \multirow{2}{*}{ Min-Max } & \multirow{2}{*}{$\begin{array}{l}\text { Mean } \\
\text { SD }\end{array}$} & & \multicolumn{4}{|c|}{ Scores } \\
\cline { 5 - 7 } & & & \multicolumn{2}{|c|}{ Low (<60\%) } & \multicolumn{2}{|c|}{ High ( $\geq 60)$} \\
\cline { 5 - 8 } & $31.0-$ & No. & $\%$ & No. & $\%$ \\
\hline Autonomy & 100.0 & $62.3 \pm 9.7$ & 118 & 43.1 & 156 & 56.9 \\
\hline Environmental mastery & $31.0-95.2$ & $64.9 \pm 10.1$ & 92 & 33.6 & 182 & 66.4 \\
\hline Personal Growth & $35.7-97.6$ & $66.7 \pm 10.9$ & 85 & 31.0 & 189 & 69.0 \\
\hline Positive Relations & $31.0-97.6$ & $64.1 \pm 10.9$ & 102 & 37.2 & 172 & 62.8 \\
\hline Purpose in life & $23.8-95.2$ & $63.5 \pm 11.6$ & 122 & 44.5 & 152 & 55.5 \\
\hline Self-acceptance & $26.2-92.9$ & $62.7 \pm 10.9$ & 114 & 41.6 & 160 & 58.4 \\
\hline Total score & $47.2-84.1$ & $64.0 \pm 7.1$ & 78 & 28.5 & 196 & 71.5 \\
\hline
\end{tabular}

Table (2): Work motivation domains scores among studied staff nurses ( $\mathrm{n}=274)$.

\begin{tabular}{|c|c|c|c|c|c|c|}
\hline \multirow{3}{*}{$\begin{array}{l}\text { Work } \\
\text { Domains }\end{array}$} & \multirow{3}{*}{ Min-Max } & \multirow{3}{*}{$\begin{array}{l}\text { Mean } \pm \\
\text { SD }\end{array}$} & \multicolumn{4}{|c|}{ Scores } \\
\hline & & & \multicolumn{2}{|c|}{$\begin{array}{l}\text { Low } \\
(<60 \%)\end{array}$} & \multicolumn{2}{|c|}{ High $(\geq 60)$} \\
\hline & & & No. & $\%$ & No. & $\%$ \\
\hline Intrinsic Motivation & $33.3-95.0$ & $66.5 \pm 10.7$ & 58 & 21.2 & 216 & 78.8 \\
\hline Extrinsic Motivation & $25.0-100.0$ & $69.1 \pm 12.9$ & 56 & 20.4 & 218 & 79.6 \\
\hline Total score & $32.5-97.5$ & $67.8 \pm 10.6$ & 62 & 22.6 & 212 & 77.4 \\
\hline
\end{tabular}


Table (3): Correlation between psychological well-being domains and total scores of work motivation.

\begin{tabular}{|l|l|l|}
\hline \multirow{2}{*}{ Psychological Well-Being Domains } & \multicolumn{2}{|l|}{$\begin{array}{l}\text { Total Work Motivation } \\
\text { Score }\end{array}$} \\
\cline { 2 - 3 } & R & P \\
\hline Autonomy & 0.205 & $0.001^{*}$ \\
\hline Environmental Mastery & 0.163 & $0.007^{*}$ \\
\hline Personal Growth & 0.140 & 0.020 \\
\hline Positive Relations & 0.234 & $<0.0001^{*}$ \\
\hline Purpose in Life & 0.215 & $<0.0001^{*}$ \\
\hline Self-acceptance & 0.291 & $<0.0001^{*}$ \\
\hline Total Score & 0.314 & $<0.0001^{*}$ \\
\hline
\end{tabular}

Table (4): Correlation between psychological wellbeing domains and intrinsic work motivation among studied staff nurses.

\begin{tabular}{|c|c|c|}
\hline \multirow[t]{2}{*}{ Psychological Well-Being Domains } & \multicolumn{2}{|c|}{$\begin{array}{l}\text { Intrinsic Work motivation } \\
\text { Score }\end{array}$} \\
\hline & $\mathbf{R}$ & $\mathbf{P}$ \\
\hline Autonomy & 0.134 & 0.027 \\
\hline Environmental mastery & 0.118 & $0.05^{*}$ \\
\hline Personal Growth & 0.09 & 0.139 \\
\hline Positive Relations & 0.181 & $0.003^{*}$ \\
\hline Purpose in life & 0.185 & $0.002 *$ \\
\hline Self-acceptance & 0.237 & $<0.0001 *$ \\
\hline Total score & 0.239 & $<0.0001 *$ \\
\hline
\end{tabular}


Table (5): Correlation between psychological wellbeing domains scores and total extrinsic work motivation among studied staff nurses $(n=274)$.

\begin{tabular}{|l|l|l|}
\hline \multirow{2}{*}{ Psychological Well-Being Domains } & \multicolumn{2}{l|}{ Extrinsic Work Motivation Score } \\
\cline { 2 - 3 } & $\mathrm{R}$ & $\mathrm{P}$ \\
\hline Autonomy & 0.227 & $<0.0001^{*}$ \\
\hline Environmental mastery & 0.170 & $0.005^{*}$ \\
\hline Personal Growth & 0.156 & 0.01 \\
\hline Positive Relations & 0.234 & $<0.0001^{*}$ \\
\hline Purpose in life & 0.200 & $0.001^{*}$ \\
\hline Self-acceptance & 0.282 & $<0.0001^{*}$ \\
\hline Total score & 0.319 & $<0.0001^{*}$ \\
\hline
\end{tabular}

\section{DISCUSSION:}

Nurses who work in hospital settings suffer from stress in the workplace, it easily affects nurses; their workplace satisfaction and performance frequent workplace stress can impact on the physical and psychological well-being of health professionals and result in burnout and, in some cases, traumatic stress-like symptoms(McCann et al.,2013). This condition threatens both the physical and psychological well-being of nurses (Suzanne, 2006).

Hospital nurses' work motivation is widely important for providing high-quality health care, (Toode, 2015). Motivation at work was found to be closely linked with job satisfaction and psychological well-being (Engin \& Com, 2006).

According to the result of the current study, most of nurses have highly autonomy and environmental mastery this may be due to nurses can control the situation and face problems and deal with it, this is supported by Madhuchandra, \&Srimathi (2016), who studied psychological well-being among doctors and nurses in India and found that nurses have high autonomy and environmental mastery compares to doctors.

One of the striking results of the present study was that most of nurses have highly personal growth, positive relation with others, purpose in life and self-acceptance. This may be due to most of nurses feel good about themselves and they are lovely with others, in addition most of them are married and achieve good purpose in life according to their 
point of view, this result in contrast with Madhuchandra \&Srimathi (2016), in India who studied psychological wellbeing among doctors and nurses.

According to the results of the current study, show that majority of nurses has a positive relation with others, and there is a significant relation between positive relation with others and both intrinsic and extrinsic motivation. In this respect, Laschinger (2009) who studied comprehensive theory of nurse/patient empowerment and founded that there is a strong relationship with physicians and nurses with nurse managers, especially facilitate the nurses' feeling of being empowered. This finding is confirmed with China (2013) who studied impact of professional nursing practice, environment and psychological empowerment on nurses' work engagement, and found that there is no positive relationship with others in the workplace, the risk of disability increases among staff.

The current results revealed that, a lot of nurses working in hospitals have both intrinsic and extrinsic motivation. This may be due to that nurses are educated to manage diagnosis and treatment in a swift and sensitive way, which may facilitate the internalization of professional standards. Their drive to maintain these standards while completing work tasks without making mistakes during critical processes may explain the great importance of internal motivation for nurses. Dealing with the stress derived from nursing practice, which arises from hard work and the great responsibility placed on their shoulders, may have increased internal self-concept-based motivation scores, as this stress, hard work, and responsibility is a challenge for which nurses are prepared.

The study findings show that there is a positive significant relation between positive relations as a domain of psychological well-being and both intrinsic and extrinsic motivation. This finding which might be due to when nurses maintain good relations with each other's this will encourage them to finish work and have inside desire toward help the patient more, so, the patient is satisfied with care and can go to manager to appreciate them and give them more incentives. This finding is confirmed with (Seixas, 2009) who believe that the interpersonal relationships of the worker, namely their relationships with patients, allow increased satisfaction or motivation at work and, consequently, better results and performance.

The results of the present study illustrated that, there is positive significant correlation between both intrinsic and extrinsic motivation of nurses and their most psychological 
wellbeing domains. This may be related to when nurses have a sense of wellbeing (have autonomy in their decision making, can control surrounding environment, has purpose in life, has good relations with others) they will be motivated to work well and do their best. The situation is similar to Toode, Routasalo, \&Suominen, (2011) who reported that extrinsic motivations are seen as having a positive effect on job satisfaction, commitment, wellbeing and health. On the same line, Gagné et al., 2010 who found that the majority of hospital nurses appeared to be motivated to work.

The results of this study revealed that, there was a statistically positive significant correlation was found between environmental mastery and autonomy psychological wellbeing domains in relation total score of work motivation. In this respect, Global Health Workforce Alliance (2008);ICN (2009); McPake et al.(2013) mentioned that work-place characteristics and working conditions support nurses' work activities and performance as nurses motivation was increased by several work-place characteristics and working conditions which supported nurses' autonomy and better work outcomes. Many hospital nurses also felt that external benefits like their reputation, the avoidance of failure, and maintaining a certain standard of living to be motivating reasons to work.

One of the striking results of the present study was that, there is statistical significant relation between personal growth and extrinsic work motivation. In this regard, Ryan \&Deci (2000); Brady (2008); Oldham \& Hackman (2010); Warr (2013);show that hospital nurses who had a stronger need for achievements, growth and self-actualization had not only higher intrinsic work motivation but also significantly higher extrinsic motivation.

The findings revealed that most of the studied staff nurses have high psychological wellbeing, this may be due to that a lot of nurses feel highly self-acceptance because they reported that they feel good about themselves when comparing them to other friends, this result is supported by Babalola \&Olumuyiwa (2015) who studied job satisfaction and psychological wellbeing among mental health nurses, and found that majority of nurses reported positive psychological wellbeing, while minority had psychological distress.

\section{CONCLUSION:}

There is a positive significant correlation between psychological wellbeing and work motivation among staff nurses in governmental hospitals in Port Said. 


\section{RECOMMENDATIONS:}

Based on the current study, the following recommendations are suggested:

- Staff nurses should try to set trustful relationships with colleagues and patients.

- Staff nurses should practice in decision making for issues related to patient care to increase their autonomy.

- Staff nurses should search for training programs to improve their personal growth and knowledge to increase the quality of care provided to the patient.

\section{REFERENCES:}

Aiken, H., Sermeus, W., Van den Heede, K., Sloane, M., Busse, R., McKee, M., Bruyneel, L., Rafferty, M., Griffiths, P., Moreno-Casbas, T., Tishelman, C., Scott, A., Brzostek, T., Kinnunen, J., Schwendimann, R., Heinen, M., Zikos, D., Sjetne, S., Smith, L. and Kutney-Lee, A. (2012). Patient safety, satisfaction, and quality of hospital care: cross sectional surveys of nurses and patients in 12 countries in Europe and the United States BMJ, 344.

Amabile TM, Conti R, Coon H, Lazenby J, Herron M. (1996). Assessing the work environment for creativity. Academy of Management Journal, 39:1154-1184.

Amabile, T.M., Hill, K., Hennessey, B.A. \&Tighe, E. (1994). The Work Preference Inventory: Assessing intrinsic and extrinsic motivational orientations. Journal of Personality and Social Psychology, 66, 950-967.

Bhardwaj A., Srivastava A. (2008). Occupational Health and Psychological Well-Being of Industrial Employees. Industrial Psychiatry Journal; 17 (1):28-32.

China Z. (2013). Impact of professional nursing practice environment and psychological empowerment on nurses' work engagement: test of structural equation modelling. J NursManag Sep 23.

Disch, J. (2002). Creating healthy work environments. Creat Nurse, 8(2):3-4.

Engin, E. and Com, O. (2006). Correlation between psychiatric nurses' anger and job motivation. Archives of psychiatric Nursing, 20(6): 208-275. 
Gagné, M., Forest, J., Gilbert, M. H., Aubé, C., Morin, E., \&Malorni, A. (2010). The Motivation at Work Scale: Validation evidence in two languages. Educational and Psychological Measurement, 70, 628-646.

Global Health Workforce Alliance (2008). Guidelines: Incentives for health professionals. Geneva: World Health Organization. Retrieved August 2, 2014,from http:// www.who.int/ workforce alliance / Incentives-Guidelines 20\% ENG 20\% low.pdf?ua=1

Huppert F. (2009). Psychological Well-being: Evidence Regarding its Causes and Consequences. Health and Well-being; 1 (2): 137-64.

International Council of Nurses (ICN) (2009).Guidelines on planning human resources for nursing.geneva: Imprimeriefornata. Retrived July 25, 2014, from http: // www.icn.ch/ images/ stories/documents/publications /guidelines /guideline planning-human-resources.pdf.

Keyes C. (2000). The Positive Organization: Leadership Legitimacy, Employee WellBeing, and the Bottom Line. The Psychologist-Manager Journal; 4 (2):143-53.

Laschinger, H. S., Leiter, M., Day, A., \&Gilin, D. (2009). Workplace empowerment, incivility, and burnout: impact on staff nurse recruitment and retention outcomes,. J Nurs Manage, 17(3): 302-311. http://dx.doi.org/10.1111/j.13652834.2009.00999.

Madhuchandra, M. K.\&Srimathi, N. L.(2016). Psychological Well-being among Doctors and Nurses: A Comparative Study, The International Journal of Indian Psychology. ISSN 2348-5396 (e) | ISSN: 2349-3429 (p) Volume 3, Issue 4, No. 68, DIP: 18.01.212/20160304 ISBN: 978-1-365-39398-3.

McCann C., Beddoe E., McCormick K., Huggard P., Kedge S., Adamson C. et al. (2013). Resilience in the health professions: A review of recent literature. International Journal of Well-being, 2013, 3(1) :60-81.

McPake, B., Maeda, A., Araujo, E.C., Lemiere, C., El Maghraby, A.A., Cometto, G. (2013). Why do health labour market forces matter? Bulletin of the World Health Organization, 91(11):841-846. 
Nemcek M, James G. (2007). Relationships among the nurse work environment,self nurturance and life satisfaction:journal of advanced nursing,59(3):240-7.

NIOSH, (2002). NIOSH Manual of analytical methods,2nd ed,vol.3,s 162,s164,s168,s310,u.s. Department of health,education, andwelfare,publ.(NIOSH)77-157-c.

Northern Ireland Civil Service. Mental Well-Being at Work Charter 2009.

Oldham, G.R., Hackman, J.R. (2010). Not what it was and not what it will be:the future of job design research.Journal of Organizational Behavior,31(2-3) :463-479.

Ostraker M. (2008). Measuring motivation in dynamic organization a contingency approach, strategic change, 3rd Ed. Mosby comp., USA, Pp.103-105.

Registered Nurses' Association of Ontario (RNAO) (2008). Healthy Work Environments Best Practice Guidelines: Workplace Health, Safety and wellbeing of the nurse Toronto, Canada, 19 February.

Ryan, R. M., \&Deci, E. L. (2000). Intrinsic and extrinsic motivations: classic definitions and new directions. Contemporary Educational Psychology, 25, 54-67.

Ryff CD. (1989). Happiness is everything,or is it ?Explorations on the meaning of psychological wellbeing. Journal of personality and social psychology 57:10691081 DOI10.1037/002-3514.57.6.1069.

Ryff, C.D. (1995). Psychological Well-Being in Adult Life. Blackwell Publishing on behalf of Association for Psychological Science, 4(4): 99-104.

Ryff, D. and Keys, C.L.M. (1996). The structure of psychological well-beingn revisited. J Personal Social Psychol.; 69: 719-27.

Samith G.P. (2009). Motivation in human resources management and development handbook. ed., Pp.(70-90):New York: Amaco.

Sexias (2009). Satisfaco Professional doEnfermerio do Servico de Urgencia ".Porto Universidade Fernando Pessoa. 
Srinivasan, K., Samuel, U. (2014). Psychological problems factors faced by staff nurses working in hospitals., Vol. 19, Issue 3, Ver. II, P. 01-04.

Suominen T., Leino-Kilpih., Merj AM., Doran D.I., PUUKKA P. (2008): Staff empowerment in finish intensive care units, Intensive and critical care nursing, 17(8):341-34.

Suzanne H. (2006). Point of care testing impacts patient flow. Nursing Critical Care; (4): 9-10.Retrieved from: http:// gateway.ut.ovid. Com/ gwl/ovidweb.cgi.

Toode, K., Routasalo, P., Helminen, M., Suominen, T. (2015). Hospital nurses'working conditions in relation to motivation and patient safety. Nursing Management, 21(10): 31-41. DOI: $10.7748 /$ nm. 21.10.31. e1293.

Toode, K., Routasalo, P., Suominen, T. (2011). Work motivation of nurses: Aliterature review. International Journal of Nursing Studies, 48(2): 246-257. DOI:10.1016/j.ijnurstu.2010.09.013.

Toode, K., Routasalo, P., Suominen, T. (2011). Work motivation of nurses: A literature review.International Journal of Nursing Studies, 48(2):246-257.

Trossaman J.A., Landeweerd G.E., Tummers GG. (2006). A comparative study of organizational characteristics, Work characteristics and nurses psychological work reactions in a hospital and nursing home settings, International Journal of Nursing Studies,43(4):491-505.

Warr, P. (2013). Jobs and job-holders: Two sources of happiness and unhappiness. In the Oxford Handbook of Happiness (David, S.A., Boniwell, I. \& Ayers, A.C.,eds): Oxford University Press, Oxford, UK, pp.733-750.

World Health Organization (2012).The World Health Report - Mental Health: New Understanding, New Hope. 2001. Available at: http://www.who.int/entity/whr/ len. 
العلاقة بين الصحة النفسية و التحفيز تجاه العمل بين الممرضات فى المستشفيات

\section{الحكومية فى بورسعيد}

أ.د.أمل صبحى محمود1، أ.م.د.وفاء عبد العظيم الحسينى2، علا محمود هلال 3

أستاذ التمريض النفسى و الصحة العقلية كلية التمريض- جامعة بورسعيد،أستاذ مساعد إدارة التمريض كلية التمريض - جامعة قناة السويس، ماجستير إدارة التمريض- كلية التمريض- جامعة بورسعيد

\section{الخلاصة}

ان المرضات هم الفئة الكبرى بين مقدمى الخدمة فى المجال الصحى وهم يو اجهون مشاكل صحية و نفسية لانهم يتعاملون مع المرضى مباثرة و لايهم مسؤلية الحفاظ على صحة المرضى،أن تحفيز المررضات هو مفتاح نجاح المنظمة ولكى يستطيع المدير تحقيق ذلك فهو يحتاج الى فهم عميق للدو افع التى تحفز الممرضات حيث يعتبر

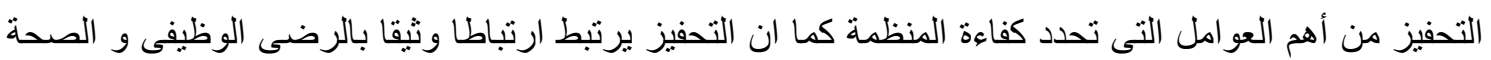
النفسية و من هنا تظهر أهمية هذه الدراسة لفحص العلاقة بين الصحة النفسية و تحفيز الممرضات تجاه العمل بين المررضات فى المستشفيات الحكومية فى بورسعيد.وقد أجريت هذه الدراسة فى أربعة مستشفيات وهى (بورسعيد

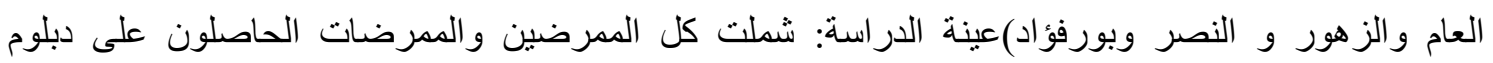
تمريض و يعملون في الاقسام الداخلية فى المستشفيات السابق ذكرها و عددهم (274). تم جمع البيانات باستخدام أداتين، الأولى: استمارة لتقييم الصحة النفسية للممرضات، و الثانية: استمارة لتقييم التحفيز للممرضاتباتلاضافة الى لى استمارة أسئلة عن البيانات الثخصية و الوظيفية للممرضات.وقد أظهرت نتائج الدراسة أن أن الممرضات الذينية لديهم مستوى عالى من الصحة النفسية تبلغ نسبتهم 71,5\% وأن اغلب الممرضات لديهم شعور بالنمو الذاتى و بلغت نسبتهم 69\% فى حين ان ما يقارب ثلثين عدد الممرضات الذين لديهم تكيف مع البيئة بلغت نسبتهم 66,4\%؛ و من ناحية أخرى فأن أقل من نصف الممرضات لديهم درجات قليلة من الاستقلالية و الهدف فى الحياة فان نسبتهر

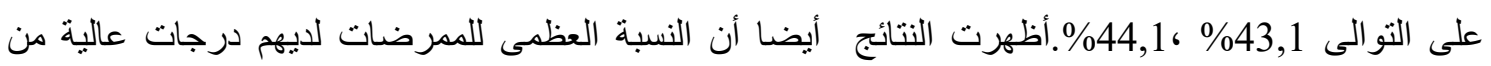
التحفيز نحو العمل ،بالاضافة الى ذلك أن أكثرهم لديهم تحفيز خارجى بنسبة 79,6\% ويوجد علاقة ايجابية بين الصحة النفسية و التحفيز تجاه العملبين الممرضات فى المستشفيات الحكومية فى بورسعيد، لذا فأوصت الدراسة بضرورة تغلب الممرضات على تحديات بيئة العمل وذلك لتحسين الصحة النفسية كما يجب على المديرين تحفيز الممرضات من خلال وضع سياسة الثواب والعقاب فيكون الثواب فى صورة صرف مكافات وحو افزاما العقاب يكون من خلال (خصم الحافز الثهرى) و حذف اسمائهم من قائمة التكريم.

الكلمات المرشدة: الصحة النفسية، تحفيز الممرضات للعمل. 